UNIO - EU Law Journal. Vol. 7, No. 1, July 2021, pp 18-32.

®2021 Centre of Studies in European Union Law

School of Law - University of Minho

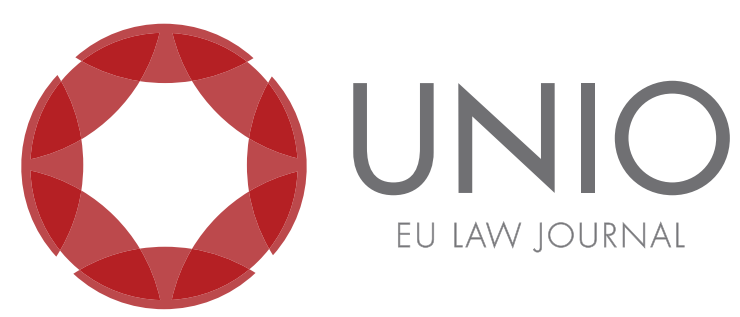

\title{
Digitalisation, pandemics and current world (2019-2021)
}

\section{Felipe Debasa*}

ABSTRACT: The new millennium saw the collapse of the real estate bubble in the United States and, together with other variables such as the high price of raw materials, a major global economic crisis began in October 2008. In 2011, as a result of the confluence of technologies and connected objects (Internet of Things) sparked thoughts that, we began to speak the Fourth Industrial Revolution. On 31 December 2019, pneumonia of unknown origin was discovered in Wuban, capital of Hubei province, P.R. China. This unexpected event is being a driver of the great digital transformation of the world that began after the 2008 crisis.

KEYWORDS: Digitalisation - pandemics - COVID-19 - $4^{\text {th }}$ Industrial Revolution

\footnotetext{
*Professor at University Rey Juan Carlos.
} 


\section{Introduction}

At the World Economic Forum in Davos 2016, its president Schwab ${ }^{1}$ made official the term, "Fourth Industrial Revolution", which had appeared shortly after the economic crisis of October 2008. It was intended to describe the set of major social and economic changes that were building a new world. The basis of these transformations was the confluence of technologies that were rapidly spreading to processes, people and things in a scenario of hyperconnectivity known as the Internet of Things. At the same time, companies and institutions were starting a debate on the need to digitise business and services to better cope with this new revolution. However, the transformations were not taking place quickly, mainly due to the cultural resistance of society to changing models.

On 31 December 2019, Chinese authorities reported a case of pneumonia of unknown origin linked to a wholesale seafood market in the city of Wuhan, capital of Hubei province. Just two months later, on 11 March 2020, the World Health Organization recognised that this Chinese pneumonia called COVID-19 had put the world in a pandemic situation. Overnight, the fortuitous event radically changed our history, forcing us to live closed in on ourselves and our places of residence. However, thanks to the incipient revolution that began in 2016 on the digitalisation of society, the world was not paralyzed by the global pandemic. The purpose of this research is to establish how COVID-19 accelerated the social transformations necessary for digitalisation.

This research has been carried out with the use of different methodological approaches to strengthen the exploratory results, specifically: specialised bibliography, ${ }^{2}$ study of legal texts and semi-structured interviews.

\section{The fortuitous event in history}

A fortuitous event ${ }^{3}$ is an unexpected event that appears unnoticed, causing major changes and transformations in society and altering the course of history.

The most representative example in this regard is the Sarajevo Attack, the assassination of Archduke Franz Ferdinand of Austria by Gavrilo Princip on behalf of the Black Hand organization. The attack, a fortuitous and unexpected event, acted as a catalyst for latent feelings and caused major transformations in the course of history. It was the contributing cause of World War I, a wound that was not closed until the end of World War II with the Schumann Declaration of 9 May 1950, the legal basis of the European Union. The resulting society after the fortuitous event in history will be different from the one, we found ourselves in before the unexpected event.

\footnotetext{
${ }^{1}$ K. Schwab, La cuarta revolución industrial (Debate, 2016).

${ }^{2}$ See about it: A. Brodeur, D. M. Gray, A. Islam and S. Bhuiyan, "A literature review of the economics of COVID-19”, IZA Institute Labor Economics, v. 13411 (2020); R.Baldwin and B. W. Di Mauro, Economics in the time of COVID-19: a new eBook (London: CEPR, 2020).

${ }^{3}$ J. M. Azcona, "Sesión del Grupo de Expertos de la Cátedra Santander Presdeia URJC", Archivo FDN, diciembre de 2020.
} 


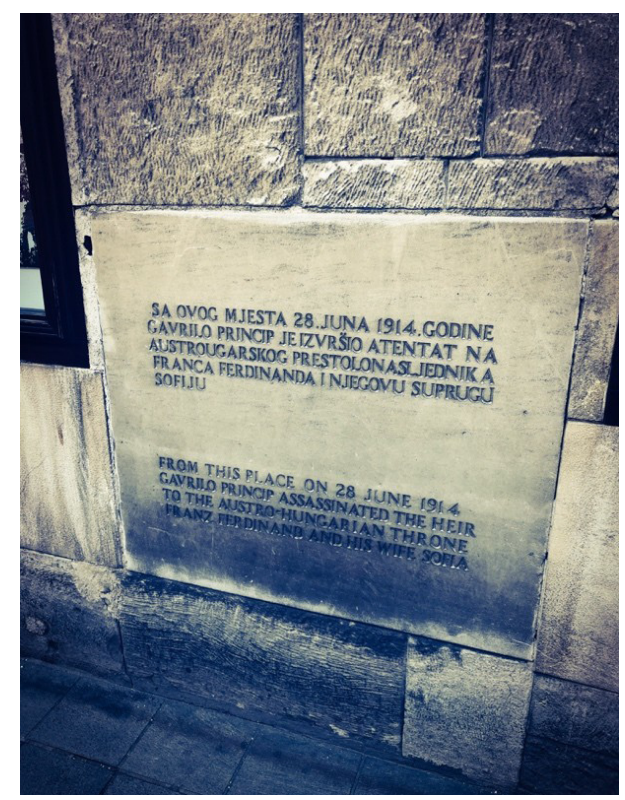

Sarajevo attack, photo by Felipe Debasa

\section{The invisible enemies of mankind}

During the 20th century, between 68 and 85 million people died worldwide because of world wars, purges, holocausts, and famine caused by war. ${ }^{4}$ After the fall of the Berlin Wall and the demise of the USSR, Huntington argued that with the disappearance of two of the traditional Cold War blocs, the next conflicts in the world could be caused by civilizations ${ }^{5}$ and not nation states. However, with the arrival of the 21 st century, other types of conflictsappeared on the scene that transcended the traditional confrontations between two countriesor two factions, as the world is fully interconnected. The most relevant of these were Afghanistan after 09/11, then Iraq and later against Daesh, and the Syrian war, which is in danger of becoming chronic. However, the most important natural enemies of humans are viruses and bacteria. The great pandemics in human history have been caused by the interaction between humans and wild animals in a process known as zoonosis. And after the last pandemic of the COVID-19, ${ }^{6}$ some voices warn that we will have to rethink the relationship between humans and wild animals. Similarly, due to globalisation, in recent years they have been warned that the emergence of a new global virus in a globalised and interconnected world would radically change our way of life.

The testimony of Bill Gates in 2015 is particularly well known in this regard, ${ }^{7}$ titled: the next epidemic? We are not ready. The 21 st century has already seen four pandemics of relevance. The 2003 Chinese bird flu, the 2009 AH1N1 influenza, also known as the Mexican flu, the 2013 Ebola virus, named after the Ebola River and the 2019 Covid or Wuhan coronavirus.

\footnotetext{
${ }^{4}$ J. M. Azcona Pastor, Historia del Mundo Actual (1945-2005) (Madrid: Universitas, 2005).

${ }^{5}$ S. P. Huntington, “The clash of civilizations?”, in Culture and politics ( New York: Palgrave Macmillan, 2000), 99-118.

${ }^{6}$ T. Ahmad, M. Khan, T. H. M. Haroon, S. Nasir, J. Hui, D. K. Bonilla-Aldana and A. J. RodriguezMorales, "COVID-19: Zoonotic aspects", Travel Medicine and Infectious Disease, no. 36 (2020).

${ }^{7}$ B. Gates, “¿La próxima epidemia? No estamos listos”, accessed January 9 $9^{\text {th }}, 2021$, https://www.ted. com/talks/bill_gates_the_next_outbreak_we_re_not_ready?hc_location=ufi\&language=es.
} 
The Wuhan coronavirus is particularly contagious and emerged at a time of great social connectivity on the planet owing to development and the Fourth Industrial Revolution. In the year before it appeared, in 2018, an average of almost 100,000 flights per day, involving the movement of 12 million people per day, were taking place around the world. On 24 July 2019, the record number of daily operations in the history of aviation was recorded at 225,000 flights, a figure that will probably not be surpassed for many years due to some of the reasons that are analysed in this paper. $^{8}$

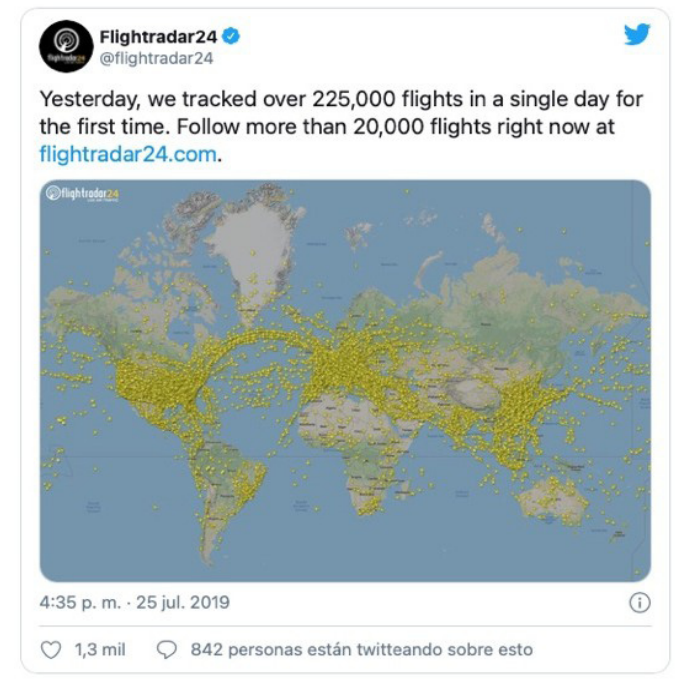

World air operations record before the COVID-19 pandemic. Screenshot by the Author

COVID-19 emerges as a fortuitous event (Azcona) that has a transcendent impact on society, generating chaos of great dimensions. After this impact, society reorganises itself in a resilientmanner, but the resulting scenario will be different from the one before the pandemic. The millennial ${ }^{9}$ generation scenario in the present world is significant. Without ever going to war or armed conflict, they already have as their vital experience overcoming a global economic crisis and a global health crisis.

\section{The historical origin of pandemics}

The history of mankind cannot be analysed without considering the history of disease. The average life expectancy in the world until the arrival of the 20th century was no more than 40 years. Throughout history, mankind has suffered numerous plagues and epidemics in which mortality was between $30 \%$ and $50 \%$ in those places where the diseases appeared. If we compare previous pandemics with the current one, this means that more than 2319 million people should have died in the world by now, representing $30 \%$ of the United States Census Bureau's census of 7730 million inhabitants. However, as of 16 February 2021, the global death toll from the COVID-19 pandemic is 2.41 million, according to various sources such as The New York Times.

\footnotetext{
${ }^{8}$ Flightradar24, application that collects in real time all the air operations that take place in the world, accessed January 1 1st, 2021, https://www.flightradar24.com/blog/satellite-based-ads-b-data-nowavailable-to-all-flightradar24-users/.

9 J. R. Saura, F. Debasa and Reyes-Menéndez, "Does user generated content characterize Millennial's Generation behavior? Discussing the relation between SNS and open innovation", Journal of Open Innovation: Technology, Market, and Complexity, v. 5, no. 4 (2009): 96, doi: 10.3390/joitmc5040096.
} 
The first plague recorded in the West was the plague of Athens, ${ }^{10}$ in Greece in $430 \mathrm{BC}$, set in the context of the Peloponnesian Wars. It was an epidemic that appeared in the most important and populated cities of Greece and lasted four years, killing more than 100,000 people, which represented a third of the population at the time. The historian Thucydides gives a great description in his General History of the Peloponnese. ${ }^{11}$ This story is still relevant today because of its medical interest. In the case of the plague of Athens, we could say that it is with the building of empires and the structuring of the world through trade and war that viral and bacterial infections made the leap from the local to the global, becoming pandemics.

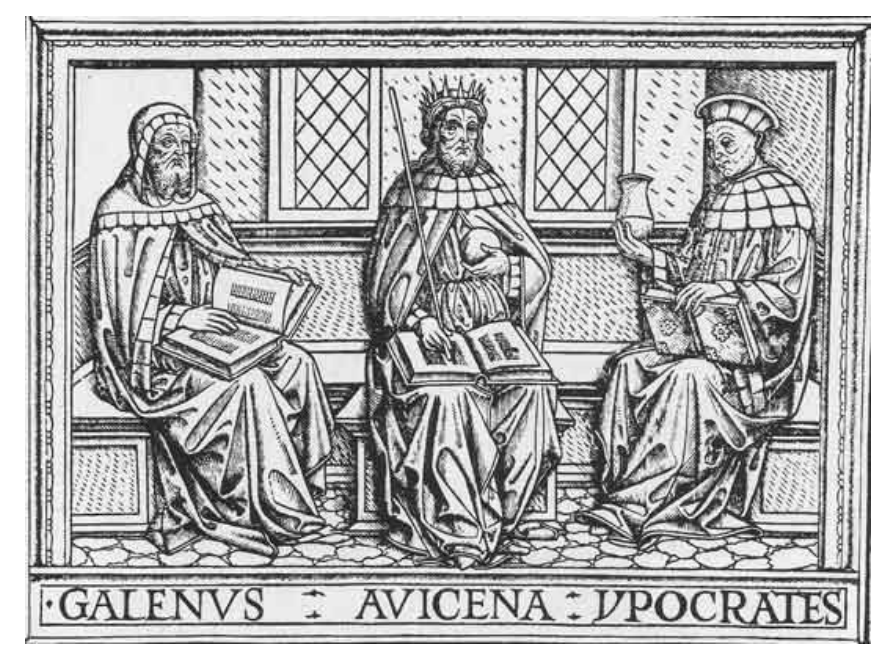

Doctors: Galen, Roman; Avicenna, Persian; and Hippocrates, Greek.

The second plague would be the plague of Antonine or Galen plague, ${ }^{12}$ which appeared in 165 and lasted for at least fifteen years. It is considered the first great global plague in history and had a mortality rate of over 10\%. At that time in history, the Roman Empire occupied all the lands on both sides of the Mediterranean Sea and almost all the Black Sea. This plague appeared at the time of the territorial consolidation of the Roman Empire. Galen of Pergamon was a physician of gladiators who ended up transcending his name by studying the plague, to the point that in some parts of Europe the name Galeno is synonymous with physician.

The third plague will be the Plague of Justinian 541-543. ${ }^{13}$ A pandemic that appeared in the middle of the $6^{\text {th }}$ century and once again swept through the Roman Empire. It was particularly severe in areas with a seaport. It would disappear a few years later, leaving a trail of between 25 and 50 million dead, which could represent between 15 and $25 \%$ of the world's population. During Justinian's plague, wealthier people fled the cities and built houses in the countryside, rediscovering the quiet

\footnotetext{
${ }^{10}$ J. Dagnino, “¿Qué fue la plaga de Atenas?”, Revista Chilena de Infectología, v. 28, no. 4 (2011): 374-380. ${ }^{11}$ Tucídides, Historia de la guerra del Peloponeso, Traducida del griego Gracián D. (Madrid: Viuda de Hernando, 1889), 147-210, https://books.google.es/books?id=-cIzAQAAMAAJ\&pg=RA1-PP2 $\& \mathrm{dq}=$ Historia $+\mathrm{de}+\mathrm{la}+$ guerra $+\mathrm{del}+$ peloponeso + tucidides + gracian $\& h \mathrm{l}=\mathrm{es} \& \mathrm{sa}=\mathrm{X} \& \mathrm{ved}=2 \mathrm{ahUK}$ EwiQ_KWy1ZvvAhVFBGMBHdDBCgYQ6AEwAHoECAIQAg\#v=onepage\&q=Historia $\% 20$ de $\% 201 \mathrm{la} \% 20$ guerra $\% 20 \mathrm{del}^{2} \% 20$ peloponeso $\% 20$ tucidides $\% 20$ gracian\&f=false.

${ }^{12}$ A. Sáez, "La peste Antonina: una peste global en el siglo II dC", Revista Chilena de Infectología, v. 33, no. 2 (2016): 218- 221.

${ }^{13}$ D. M. Wagner, J. Klunk, M. Harbeck, A. Devault, N. Waglechner, J. W. Sahl and H. Poinar, "Yersinia pestis and the Plague of Justinian 541-543 AD: a genomic analysis", The Lancet infectious diseases, v. 14, no. 4 (2014): 319-326.
} 
life away from stress. We have seen this situation in Europe today with COVID-19, which has redefined the map of the property market. The poet Horace captures it in Epodos, 2, 1, which we summarise today with the expression "Beatus Ille":

Blessed is he, who far from business deals, like the first race of mortal men, works his father's lands with his own oxen, freed from all the money lending;

no soldier is he, harsh bugle-called, no ill-tempered sea does he fear,

but shuns the forum, the haughty doorways of city folk more powerful.

In this way, he marries the tall poplars with the mature shoots of grapevines, or in a far off valley of bawling cattle looks at the errant herds,

or, pruning off the dead branches with a hook, grafts on more rewarding ones, or stores up extracted honey in clean jars or shears the unsteady sheep; or, when fall raises its head glorious with ripe fruit above the fields,

how glad he is picking grafted pears and the grape vying with purple dye!

It is significant how these verses from the Beatus Ille described the situation during the plague of Justinian and during the COVID-19, fourteen centuries later. It seems that the source of Justinian's plague was Yersinia Pestis, a bacterium of animal origin discovered by Alexandre Yersin, ${ }^{14}$ which is transmitted by zoonosis from rats to humans causing an infection in the body visibly manifested by large blisters called buboes. The conclusion about the origin of the bacterium has recently been possible thanks to the study of the teeth of some corpses from which genetic material has been extracted for study by means of a certain technique.

The second great pandemic in history was the Black Death 1347-1353. ${ }^{15}$ It ravaged Europe, Asia and North Africa and the death toll is estimated at between 75 and 200 million. It probably did not disappear until the end of the 15th century. It should not be confused with the bubonic plague, which is a different disease, although it has common symptoms. The Black Death is considered one of the events that ended the Middle Ages and ushered in the Modern Age. But on a more contemporary reading, in which we find ourselves, is that it is the fortuitous event that gave rise to the Renaissance. The high number of deaths in Europe, probably between 30 and $50 \%$ of the total population, from a pandemic that had been raging in European society for more than a century, made it necessary to look for answers beyond religion. Thus, an empirical spirit was forged, which also placed the human being at the center of the construction of the object of existence. The origin of the Black Death was also the Yersinia Pestis bacterium, although another variant of the Plague of Justinian, according to recent studies. Both the Justinian Plague and the Black Death became widespread through zoonosis between rats and humans.

\footnotetext{
${ }^{14}$ B. J. Hawgood, "Alexandre Yersin (1863-1943): discoverer of the plague bacillus, explorer and agronomist", Journal of medical biography, v. 16, no. 3 (2008): 167-172.

${ }^{15}$ See about it: R. S. Gottfried, Black death (New York: Free Press, 1985); O. J. Benedictow and O.L. Benedictow, The Black Death, 1346-1353: the complete history (Woodbridge and Rochester: Boydell Press, 2004), 412-413; D. Herlihy, The Black Death and the transformation of the West (Cambridge: Harvard University Press, 1997); K. I. Bos, V. J. Schuenemann, G. B. Golding, H. A. Burbano, N. Waglechner, B. K. Coombes and J. Krause, "A draft genome of Yersinia pestis from victims of the Black Death", Nature, v. 478, no. 7370 (2011): 506-510.
} 


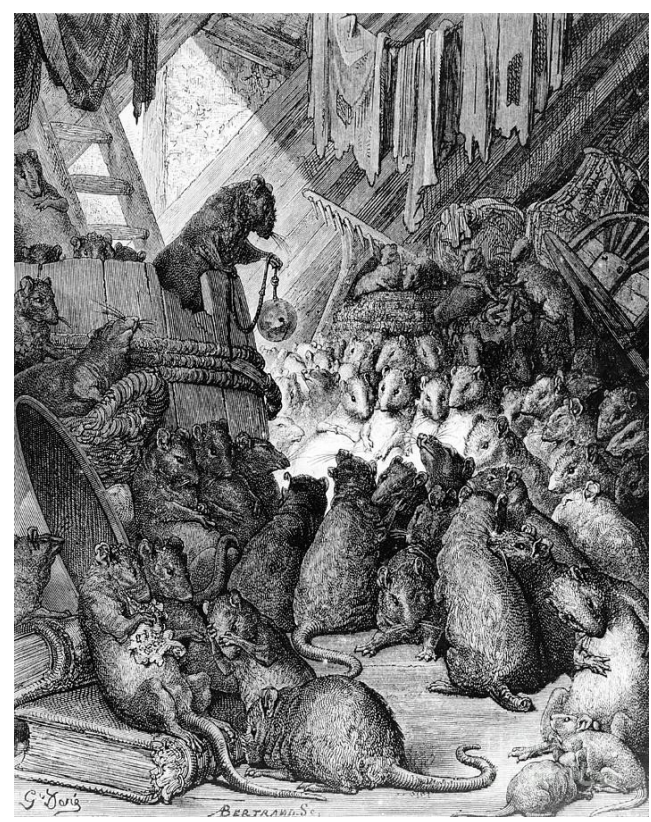

1Illustration for The Council beld by rates. Gustav Dore, 1868

Rats have been animals that have coexisted with humans throughout history because of the ecosystem that is created around the human way of life in which it is easy for the rat to find shelter, cover and food. Particularly significant is this rathuman symbiosis in life on board ships and in navigation. As a result of the Black Death, the word quarantine appeared in the Republic of Venice. Ships arriving in the Republic of Venice had to wait forty days in front of the port before disembarking. And why forty and not thirty or forty-five? Because of the ritual significance of the number forty. These are the days that Jesus was in the desert, the decades that the Jews were enslaved in Egypt, the years that the Jews were marching in the desert and the days of Lent. So the word quarantine comes from the Italian cuarenta giorni. ${ }^{16}$ Inside ships, rats formed an ecosystem with humans to such an extent that it was recommended that they should not be killed and should be left alone, as in times of food shortage they were an excellent delicacy. And of course, when they arrived in port, they would get on and off the ship like any other passenger, interacting with the local rats and transmitting diseases.

On rats and life on board we attach the following testimonies. Pigafetta, chronicler of the Magellan-Elcano expedition, describes that on leaving the Strait of Magellan on 28 November 1520 they had already run out of fresh and good food, and for four months while crossing the Pacific Ocean the diet consisted of: "remains of sponge cake turned into powder mixed with maggots and rat urine. Cow's horns that had been used to line the big cock, which was dipped for four or five days in the sea to soften it and then grilled. Sometimes they ate sawdust. But rats, so repellent to humans, became such a delicate food that they were paid half a ducat a piece".

And so it seems that the rats were eaten without even shedding their skin. We find another reference on how to care for and look after rats on board a ship in the work of the famous bishop Guevara de Mondoñedo ${ }^{17}$ "The inventors of the art of

${ }^{16}$ F. Debasa, "Nos jugamos el modelo socioeconómico", OK Diario, March 23 $3^{\text {th }}, 2020$, https:// okdiario.com/espana/historiador-debasa-sobre-crisis-del-corona-virus-nos-jugamos-modelosocioeconomico-5316775.

${ }^{17}$ A. Guevara, Libro de los inventores del arte de marear, y de muchos trabajos que se pasan en galeras (Pamplona: 
seafaring, and of many jobs that are spent in galleys": "It is the privilege of the galley that all mice and dormice are daring and free, so that they can, without any penalty, steal from the passengers, touching cloths, silk waistcoats, handkerchiefs, old shirts and even marinated gloves for them to sleep in, so that they can give birth in them and raise their children, and so that they can gnaw at them when there is no food to eat. And don't be angry, brother passenger, if the mice ever bite you while you are sleeping, because on my way from Tunisia to Sicily they bit me on an ear and a leg, but as I swore the privileges of the galley, it didn't occur to me to say anything to them".

This reference by Bishop Guevara suggests that rats represented a protein reserve in case of hardship. The inclusion of this type of animal in the diet has been more frequent throughout history than our current cultural perception would suggest.

Such pests are usually acquired through the bite of fleas that have previously bitten sick rodents and carry the Yersinia Pestis bacterium. However, research has also shown that plague can also be contracted by eating the meat or offal of infected animals. ${ }^{18}$ This is one of the hypotheses for the origin of the Wuhan coronavirus or COVID-19: eating pangolin meat. ${ }^{19}$

\section{Current world}

We are in a period known as the Fourth Industrial Revolution, or Industry 4.0, characterised by the convergence of different technologies and the hyperconnection of things and people. ${ }^{20}$ The concept was coined by Klaus Schwab at the World Economic Forum in Davos in 2016. ${ }^{21}$ Schwab put forward the idea that the boundaries between the physical, the digital and the biological were disappearing. A complementary definition is that everyday activities that used to take place in well-defined physical and geographical settings are transcending themselves to be carried out in a new digital setting that requires new governance, management, control, and development mechanisms. ${ }^{22}$

As a result, the institutions are encouraging companies to adapt as quickly as possible to this new scenario of the 4th Industrial Revolution in a process known as digitalisation. ${ }^{23}$ To this end, since 2017 the European Commission has been producing the DESI, the Digital Economy and Society Index. ${ }^{24}$ It is an index that analyses relevant indicators on digitisation in Europe and the Member States. It comprises five values that make it possible to track the evolution of the European Union Member States. ${ }^{25}$

\footnotetext{
Tomas Porralis, 1579), 24-30.

${ }^{18}$ A. A. B. Saeed, N. A. Al-Hamdan and R. E. Fontaine, "Plague from eating raw camel liver", Emerging infectious diseases, v. 11, no. 9 (2005): 1456-1457, https://dx.doi.org/10.3201\%2Feid1109.050081.

${ }_{19}$ T. Zhang, Q. Wu and Z. Zhang, "Probable pangolin origin of SARS-CoV-2 associated with the COVID-19 outbreak", Current Biology, v. 30 (2020): 1346-1351, doi: 10.1016/j.cub.2020.03.022.

${ }^{20}$ F. Debasa F, "Un análisis transversal para un derecho interalgoritmos. Nuevos retos sociales en la IV Revolución Industrial”, Telos: Cuadernos de comunicación e innovación, v. 109 (2018): 126-131.

${ }^{21}$ Schwab, La cuarta revolución industrial.

${ }^{22}$ Debasa, "Un análisis transversal para un derecho interalgoritmos", 126-131.

${ }^{23}$ A. Landeta Etxeberria, "Kit pymes «estrategia digital»: un modelo sintético para facilitar la elaboración del plan de evolución de la estrategia digital en el marco de la industria 4.0", Revista de Contabilidady Tributación, v. 435 (2019): 163-200.

${ }^{24}$ V. Russo, "Digital Economy and Society Index (DESI). European guidelines and empirical applications on the territory", in Qualitative and Quantitative Models in Socio-Economic Systems and Social Work (Sevilla: Springer, 2020), 427-442.

${ }^{25}$ European Commission Studies, "Índice de Economía y Sociedad digital”, accessed January 1', 2020, https://administracionelectronica.gob.es/pae_Home/pae_OBSAE/Posicionamiento-Internacional/ Comision_Europea_OBSAE/Indice-de-Economia-y-Sociedad-Digital-DESI-.html\#.X-92Wy0rzUZ.
} 


\begin{tabular}{|c|}
\hline Connectivity \\
\hline Human capital \\
\hline Internet use \\
\hline Digital technology integration \\
\hline Digital public services \\
Digital Economy and Society Index (DESI), from European Commission
\end{tabular}

At the same time as Schwab was calling for a new era, traditional business was calling for a roadmap to cope with the new situation. This is what is known as the Digital Enterprise.

Alberto Delgado ${ }^{26}$ proposed in 2016 the following 12-step path to turn the traditional company into a digital company. The first step for the digitisation of the company is to change the traditional marketing for digital marketing. ${ }^{27}$ In the first case, conventional strategies based on very few elements were analysed. In the case of Digital Marketing, the analysis of large volumes of data and information that must be carried out with computer tools is required. This is how Big Data appeared.

1. Digital marketing

2. Digital commerce

3. Social media

4. Digital analytics

5. Digital processes

6. Digital collaboration

7. Digital innovation

8. Digital skills

9. Digital knowledge

10. Digital roles

11. Digital platform

Once the company has gone through all the steps, it reaches the finish line. This is when thecompany is ready to create fully digital jobs. This is the real social transformation. But for this scenario to be possible, States and the European Union must regulate telework. In Spain, the most prominent studies on telework are from $2016 .{ }^{28}$ Until the advent of the COVID-19 pandemic, telework was a kind of utopia, timidly implemented for the self-employed, but very weakly for employees. We affirm that the digitisation of the company consists of automating processes with technology. Technology is necessary to analyse large volumes of datainvisible to

\footnotetext{
${ }^{26}$ A. Delgado, "Digitalíate: cómo digitalizar tu empresa (Bogotá: ECOE Ediciones, 2016).

27 J. R. Saura, "Using data sciences in digital marketing: framework, methods, and performance metrics", Journal of Innovation and Knowledge, v. 1 (2020), doi: 10.1016/j.jik.2020.08.001.

28 A. de las Heras García, El teletrabajo en España: un análisis crítico de normas practices (Madrid: Centro de Estudios Financieros, 2016); A. de las Heras García and F. Debasa, "Retos, desafíos y oportunidades del mercado laboral español" (summer course of the Universidad Internacional Menéndez Pelayo, Santander, July 20-22, 2016) Program: https://wapps001.uimp.es/uxxiconsultas/ ficheros/7/37083mercado.pdf.
} 
the human eye. The digitisation of the company began with the mechanisation of processes in the 20th century. Technology was not used here, but automatic mechanical processes were used. The most famous example is Henry Ford's chain manufacturing. Other examples after the Second World War would be automatic restaurants, in which physical contact between staff and customer disappeared.

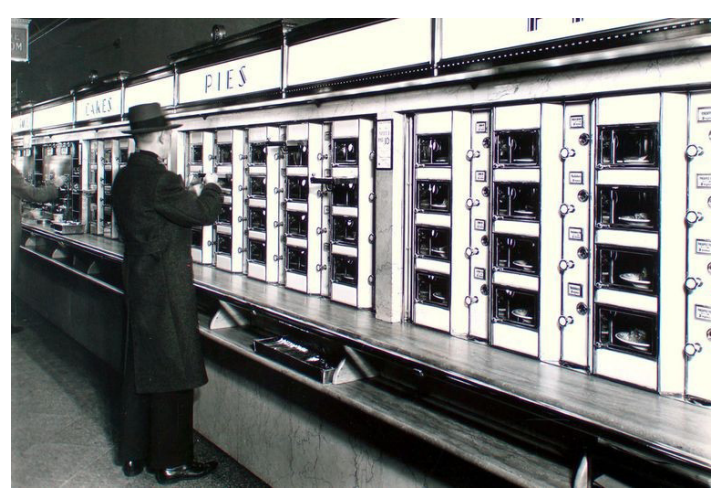

Automatic restaurant in the 20 th century

\section{The scenario from $31^{\text {st }}$ December 2019}

Spain suffered a major economic crisis at the beginning of the last decade of the $20^{\text {th }}$ century. At that time, concepts such as employment sources were coined, proposing an active search by the administrations and social agents for new jobs. ${ }^{29}$ Spain recovered economically at the end of the decade and this idea was forgotten. However, we found from the studies of that time that the characteristics of the jobs that appeared in the employment sites were mobility and flexibility, far removed from the traditional concept of work in an immobile place such as a factory. An employment field was defined as the economic sector that was going to demand labor in the future, due to social transformation. To achieve the objectives of mobility and flexibility, it is important to have technological and communication tools, and at the end of the last century, these were still in their infancy. However, small steps were being taken at European level, such as the European Framework Agreement on Telework, signed by the European social partners in July 2002 and revised in 2009.

On $31^{\text {st }}$ December 2019, a pneumonia of unknown origin was announced, which was causing great concern to the Chinese authorities. In March 2021, pneumonia appeared in force in northern Italy and several towns were completely closed. At the end of March, practically the entire planet's freedom of movement was restricted to a greater or lesser extent, and in many cases, people remain locked up at home, with all the consequences this has for the economy. In this scenario, companies are implementing teleworking at an accelerated pace. Even labels are being created and included in email signatures to show solidarity with people who stay at home to work. This movement is called \#Athome.

\footnotetext{
${ }^{29}$ See about it: E. Carrillo, "El patrimonio histórico como yacimiento de empleo", Ec, Cuadernos de Economía de la Cultura, v. 1 (2003): 105-110; L. C. Rodríguez, "Los mayores como yacimiento de empleo", Documentación social, v. 112 (1998): 223-235; T. Torns, "Los servicios de proximidad, cun yacimiento de empleo?”, Revista de treball social, v. 147 (1997): 40-47; E. Jiménez, J. E. Sánchez and A. Rivero, "Los nuevos yacimientos de empleo: los retos de la creación de empleo desde el territorio", Biblio3w: Revista bibliográfica de Geografía y Ciencias Sociales, v. 3 (1999); A. Vilallonga, "Los nuevos yacimientos de empleo: una oportunidad para crear empleo y satisfacer nuevas necesidades sociales”, Scripta Nova: revista electrónica de Geografía y Ciencias Sociales, v. 6, no. 119 (2002).
} 
The present research conducts five semi-structured interviews with the aim of extracting insights that can explain how the impact of the pandemic has been understood in the actual world. The interviewees are people of international social relevance whose activity forces them to be part of an interconnected world. The profile of the interviewees can be found in Annex I and the questions that make up the questionnaire can be found in Annex II.

\section{Analysis of the results}

From the interviews conducted, we have identified the eight topics that we considered mostrelevant based on the words expressed by the interviewees. Table 1 shows the topicsidentified.

Table 1. Composition of thematic nodes on the basis of relevance

\begin{tabular}{|c|c|}
\hline Topics & Similar words \\
\hline Change of era & Disruption, change, new social era. \\
\hline Technology & $\begin{array}{l}\text { Technology, zoom, family, telemeetings, } \\
\text { telework, videoconferencing, video calls, apps, } \\
\text { entertainment, Netflix. }\end{array}$ \\
\hline Travel & $\begin{array}{l}\text { Business travel, incentives to work, } \\
\text { downtime, meetings. }\end{array}$ \\
\hline Isolation & $\begin{array}{c}\text { Isolation, distress, divorces, loss of rights } \\
\text { and freedoms, borders, psychological } \\
\text { problems. }\end{array}$ \\
\hline Company & $\begin{array}{l}\text { Traditional business, digital business, } \\
\text { entrepreneurship, crisis. }\end{array}$ \\
\hline Housing & $\begin{array}{c}\text { New types of housing, caravans, camping, } \\
\text { terraces, countryside, town, villages, empty } \\
\text { places. }\end{array}$ \\
\hline Work & $\begin{array}{l}\text { Psychological problems, unemployment, digital } \\
\text { jobs, digitisation of companies, free dismissal, } \\
\text { bringing back the office and face-to-face work. }\end{array}$ \\
\hline Economic recovery & $\begin{array}{c}\text { Happy twenties, recovery, exit from the crisis, } \\
\text { happiness. }\end{array}$ \\
\hline Tourism & $\begin{array}{l}\text { Tourism, hotels, bars, discotheques, cruises, } \\
\text { aeroplanes, passports, biological passports. }\end{array}$ \\
\hline
\end{tabular}

Table of node composition. Source: Author's own elaboration 
After identifying the themes on the basis of the key words, we moved on to the descriptionof the themes as expressed in the interviews as can be seen in table 2 .

\begin{tabular}{|c|c|}
\hline Topics & Description \\
\hline Change of era & $\begin{array}{l}\text { The coronavirus is here to stay. It accelerates } \\
\text { the digital transformation of companies and } \\
\text { institutions. }\end{array}$ \\
\hline Technology & $\begin{array}{l}\text { The world survives thanks to technology. } \\
\text { Technology has minimized the impact of the } \\
\text { crisis. }\end{array}$ \\
\hline Travel & $\begin{array}{c}\text { Corporate travel will disappear because lifestyle } \\
\text { habits have changed. The world is looking } \\
\text { forward to travel again. }\end{array}$ \\
\hline Isolation & $\begin{array}{c}\text { Isolation generates uncertainty, fear, and } \\
\text { anguish. }\end{array}$ \\
\hline Company & $\begin{array}{l}\text { Entrepreneurial Darwinism dictates that only } \\
\text { prepared companies survive. }\end{array}$ \\
\hline Housing & $\begin{array}{l}\text { The pandemic has rethought new ways of life. } \\
\text { Flight from cities and open spaces. }\end{array}$ \\
\hline Work & $\begin{array}{l}\text { The pandemic promoted telework overnight. A } \\
\text { year later, some people want to go back to face- } \\
\text { to-face work. }\end{array}$ \\
\hline Economic recovery & $\begin{array}{l}\text { A coordinated response to the crisis is } \\
\text { expected. Recovery as in the happy } 20 \text { 's of } \\
\text { the } 20^{\text {th }} \text { century is expected. Joint action plans. } \\
\text { Long recovery. Isolated plans are useless. }\end{array}$ \\
\hline Tourism & $\begin{array}{l}\text { Countries that have based their economic } \\
\text { model on tourism need the vaccine and require } \\
\text { mechanisms such as the biological passport to } \\
\text { start their recovery. }\end{array}$ \\
\hline
\end{tabular}

Thematic description table. Source: Author's own elaboration

The interviews conducted show that we were already facing a change of era and that what the situation generated by COVID-19 has done is to accelerate the digital transformation of companies and institutions. The impact of the pandemic on the economy and society has been very high. It is very difficult to talk about the number of deaths because it is possible to put a face to the death caused by COVID-19. However, the death toll relative to previous pandemics in history has been reasonably low.

Technology has minimised the impact of the pandemic on both work and leisure. Ease of access to content platforms has helped to better manage confinement 
in many parts of the world. The global internet showed great strength during the initial harsher moments of 2020.

Consumption, leisure, mobility and travel habits have changed. So have work and life styles. With regard to leisure, one of the activities most in demand in today's society is to be able to travel again. However, travel agencies do not think that the pre-2020 market will be restored for some time at least, and those that expect to emerge from the crisis first are those specialising in leisure and pleasure.

In relation to teleworking, what a priori proved to be a positive element to reconcile work and family life, is arousing negative feelings a few years later. Human beings are sociable people, and this research shows that there are cases of people demanding to return to the office because of the need to have human contact again. On economic recovery, there is no clear view on when it might start. However, it has become clear that coordinated responses and action plans are needed to get out of the crisis. Acting in an uncoordinated manner could lead to even more chaos. If the digital transformation moves forward and does not go backwards, it might be interesting to revisit the employment sources proposal to analyse which sectors will emerge stronger after the crisis.

\section{Conclusions}

The creation of empires in ancient times favored the development of diseases known as plagues. Humanity has suffered several pandemics throughout history, so once this one is over, it is likely that there may soon be others. Viral, or bacterial in origin. The 2019 pandemic is causing a negligible number of deaths compared to previous pandemics in history.

Following this research, we can surmise that the emergence of COVID-19 is causing a series of major changes and transformations in society. These are more profound than was first thought. The new socialisation resulting from COVID-19 has imposed different ways of interacting between people, which is leading to a rethinking of economic activity. It is too early to see how important sectors such as business travel or office rental will be affected, although some authors speak of falls of up to $80 \%$. We can talk about other sectors that are being paralysed, such as fashion, or that have been completely paralysed, such as the cruise industry.

Thanks to technology, the difficulties caused by the virus are being overcome. It is still too early to assess the extent of the digital transformation brought about by the pandemic. Some say it has taken at least ten years. In addition to implementing the tools, society has been predisposed to change.

The most important sector during the tough periods of confinement has been the retail sec tor. Thanks to excellent preparedness, the world has hardly ever suffered from shortages except in isolated, one-off cases. Distribution will be the most important sector in the digital economy, and in relation to employment opportunities, there will be a great need for experts in logistics and big data applied to logistics.

It seems that the transformations that have been achieved cannot be reversed. It is likely that in many sectors, mixed models will coexist between the models achieved during the pandemic and those that preceded it. This research shows that the extent of the changes have not yet been analysed and that they will be much more profound than previously thought. The results of this methodological approach could define future research on sector-specific changes brought about by the pandemic. 
COVID-19 is the fourth pandemic of the 21st century, after avian flu (2003), influenza A or Mexican flu (2009) and Ebola (2013). If the world is to avoid further pandemics, it will have to rethink its relationship with wild animals. This will require a tightening of national legislation and probably greater sovereignty of international bodies over these issues in nation states. Social customs such as eating wild animals or living with wild animals will have to be rethought. Lawmakers will need to work more closely with zoologists, virologists and bacteriologists and establish new protocols for cohabitation. This research also shows that more than a year after the emergence of COVID-19, no contingency plan has yet been prepared, and wild animals are still readily available for purchase for human consumption in markets in many countries around the world. COVID-19 is ultimately a zoonosis that has changed the world as a fortuitous event in history.

The coronavirus or COVID-19 pandemic has accelerated the digital transformation process by 5 to 10 years, and that when it subsides, the resulting scenario will not be the same as in 2019, forcing companies and institutions to restructure their organisations and logistics operations.

\section{ANNEX I}

\section{Identification of the profiles interviewed}

\begin{tabular}{l|l|l}
\hline $\begin{array}{l}\text { Object of the } \\
\text { research }\end{array}$ & Job description and profile & Location \\
\hline $\begin{array}{l}\text { Identify a Spanish } \\
\text { politician with } \\
\text { government } \\
\text { responsibilities }\end{array}$ & Spanish Senator & Barcelona, Spain \\
\hline $\begin{array}{l}\text { Selecting an } \\
\text { entrepreneur with } \\
\text { traditional and } \\
\text { digitized businesses }\end{array}$ & $\begin{array}{l}\text { Entrepreneur in the education } \\
\text { sector }\end{array}$ & Madrid, Spain \\
\hline $\begin{array}{l}\text { Hospitality } \\
\text { businessman in Spain } \\
\text { with international } \\
\text { clientele }\end{array}$ & $\begin{array}{l}\text { Hotel and Catering Sector } \\
\text { Entrepreneurs }\end{array}$ & Madrid, Spain \\
\hline $\begin{array}{l}\text { Entrepreneur in the } \\
\text { tourism sector in } \\
\text { an emerging tourist } \\
\text { destination }\end{array}$ & Entrepreneur tourism services & Dubai, UAE \\
\hline $\begin{array}{l}\text { Entrepreneur in the } \\
\text { import/export sector }\end{array}$ & International Trade & Shanghai, China \\
\hline
\end{tabular}




\section{ANNEX II}

Questions asked in the interview

Question 1:

How does COVID-19 affect your professional sector or your institutional (political) activity?

Question 2:

How has your sector transformed itself to survive the pandemic?

Question 3:

Has the digital transformation in your sector been rapid?

Question 4:

Do you think that once we return to normality, will teleworking be abandoned in your sector?

Question 5:

Do you think that rural location offers opportunities for your sector? If so, why. 